\title{
THE REDUCTION OF ZINC TITANATE AND ZINC OXIDE SOLIDS
}

\author{
S. LEW, ${ }^{\dagger}$ A. F. SAROFIM and M. FLYTZANI-STEPHANOPOULOS ${ }^{\star}$ \\ Department of Chemical Engineering, Massachusetts Institute of Technology, Cambridge, MA 02139, \\ U.S.A.
}

(First received 4 February 1991; accepted in revised form 16 July 1991)

\begin{abstract}
The reduction of bulk mixed oxides of zinc and titanium of various compositions and $\mathrm{Zn}-\mathrm{Ti}-\mathrm{O}$ crystalline phases was studied in a thermogravimetric apparatus in $\mathrm{H}_{2}-\mathrm{H}_{2} \mathrm{O}-\mathrm{N}_{2}$ gas mixtures at $550-1050^{\circ} \mathrm{C}$. Comparative reduction experiments with $\mathrm{ZnO}$ were also performed. In the absence of water vapor, activation energies of 24 and $37 \mathrm{kcal} \mathrm{mol}^{-1}$ were obtained for $\mathrm{ZnO}$ and $\mathrm{Zn}-\mathrm{Ti}-\mathrm{O}$, respectively. The addition of water vapor inhibited reduction and resulted in a change in activation energy to $44 \mathrm{kcal}^{\mathrm{mol}}{ }^{-1}$ for both $\mathrm{ZnO}$ and $\mathrm{Zn}-\mathrm{Ti}-\mathrm{O}$ solids. Similar to $\mathrm{H}_{2} \mathrm{O}, \mathrm{H}_{2} \mathrm{~S}$ inhibited the initial reduction rate of $\mathrm{ZnO}$ and $\mathrm{Zn}-\mathrm{Ti}-\mathrm{O}$ materials. Based on kinetic experiments, a two-site model is proposed for $\mathrm{ZnO}$ reduction. One type of sites is characterized by a rapid reduction rate but is poisoned by water vapor as well as by the presence of titanium atoms in the solid. The other type of sites has a lower reduction rate, is not poisoned by $\mathrm{H}_{2} \mathrm{O}$, and is slowly eliminated by the presence of titanium.
\end{abstract}

\section{INTRODUCTION}

The efficient removal of $\mathrm{H}_{2} \mathrm{~S}$ from coal-derived gas streams at elevated temperatures is crucial for efficient and economic coal utilization in emerging advanced power generating systems such as the integrated gasification-combined cycle and the gasification-molten carbonate fuel cell. Typically, coal gases contain a mixture of $\mathrm{CO}, \mathrm{H}_{2}, \mathrm{H}_{2} \mathrm{O}, \mathrm{CO}_{2}, \mathrm{~N}_{2}$ and $\mathrm{CH}_{4}$. The composition of the gas mixture depends on the type of gasifier used and on the extent of the use of water for quenching. In addition to these gases, minor compounds, most of them undesirable or deleterious, such as $\mathrm{H}_{2} \mathrm{~S}$ and alkali salts, exit the coal gasifier. The relative amounts of these components depend on the type of coal and the type of gasifier used.

Previous studies (Jalan and Wu, 1980; Grindley and Steinfeld, 1981; Flytzani-Stephanopoulos et al., 1985) have investigated zinc oxide as a high-temperature, regenerable sulfur sorbent. The thermodynamic equilibrium for $\mathrm{ZnO}$ sulfidation is quite favorable, yielding $\mathrm{H}_{2} \mathrm{~S}$ concentrations as low as a few parts per million (ppm) at typical hot gas cleanup temperatures $\left(500-700^{\circ} \mathrm{C}\right)$. However, a difficulty with all sorbents containing zinc oxide is some reduction to volatile elemental zinc at temperatures above $600^{\circ} \mathrm{C}$. $\mathrm{ZnO}$ reduction by $\mathrm{H}_{2}$ has been detected at temperatures as low as $160^{\circ} \mathrm{C}$ (Bonasewicz et al., 1981). The mixed oxide sorbent zinc ferrite, $\mathrm{ZnFe}_{2} \mathrm{O}_{4}$, combining $\mathrm{ZnO}$ with $\mathrm{Fe}_{2} \mathrm{O}_{3}$, has been developed in recent years as an alternative to single zinc oxide sorbent (Grindley and Steinfeld, 1983). Zinc ferrite decomposes intu $\mathrm{ZnO}$ $+\mathrm{Fe}_{3} \mathrm{O}_{4}$ in the reducing coal gas atmosphere. Hence, it is similarly limited to an operating temperature of approximately $600^{\circ} \mathrm{C}$. In recent studies (Lew et al.,

†Present address: ARCO Chemical Company, Newtown Square, PA 19073, U.S.A.

${ }^{\ddagger}$ Author to whom correspondence should be addressed.
1989; Flytzani-Stephanopoulos et al., 1987) the combination of zinc oxide with titanium dioxide was found effective in producing bulk mixed $\mathrm{Zn}$ Ti $O$ as alternative, regenerable sulfur sorbents which may be more resistive towards reduction to volatile elemental zinc. This paper reports on kinetic and parametric studies of reduction of $\mathrm{ZnO}$ and $\mathrm{Zn}-\mathrm{Ti}-\mathrm{O}$ materials.

The reduction of $\mathrm{ZnO}$ in the temperature range of $400-1500^{\circ} \mathrm{C}$ by $\mathrm{CO}$ and $\mathrm{H}_{2}$ gases has been the subject of many studies over the years. Some of the earlier investigators (Bodenstein, 1927; Maier and Ralston, 1928) were mainly interested in the extraction of zinc from ores in a retort furnace. In more recent investigations (Truesdale and Waring, 1944; Hegedus and Kiss, 1966; Guger and Manning, 1971; Grunze and Hirschwald, 1974, 1975; Gioia et al., 1977), the reduction kinetics of $\mathrm{ZnO}$ sintered pellets, powders, and single crystals were examined with $\mathrm{H}_{2}$ as well as CO. Similar activation energies have been obtained for both reduction in $\mathrm{H}_{2}$ and $\mathrm{CO}$ (Grunze and Hirschwald, 1975). However, the frequency factor of the rate constant for reduction of $\mathrm{ZnO}$ with $\mathrm{H}_{2}$ is approximately twice as large as that with $\mathrm{CO}$.

The first study of the reduction of $\mathrm{Zn}-\mathrm{Ti}-\mathrm{O}$ mixed oxides was reported by Flytzani-Stephanopoulos et al. (1987). A lower reduction rate by as much as five times was reported for $\mathrm{Zn}-\mathrm{Ti}-\mathrm{O}$ solids compared to $\mathrm{ZnO}$ reduction by hydrogen at $650^{\circ} \mathrm{C}$. However, these experiments were carried out in a fixed-bed reactor, where mass transfer resistance might have been limiting. It has been reported by Hirschwald and Noack (1972) that it is possible to decrease the reducibility of $\mathrm{ZnO}$ by the inclusion of a small amount of foreign atoms. They found that the reduction of $\mathrm{ZnO}$ can be inhibited by the addition of small amount ( $1 \mathrm{~mol} \%$ ) of $\mathrm{Li}_{2} \mathrm{O}, \mathrm{Al}_{2} \mathrm{O}_{3}$ or $\mathrm{Ga}_{2} \mathrm{O}_{3}$. They attributed this to a change in the electronic state of zinc oxide. However, no such information exists for the addition of $\mathrm{TiO}_{2}$ into $\mathrm{ZnO}$. 
The objective of this study was to determine whether $\mathrm{Zn}-\mathrm{Ti}-\mathrm{O}$ materials are intrinsically more resistive to reduction than $\mathrm{ZnO}$ and to determine the composition of $\mathrm{Zn}-\mathrm{Ti}-\mathrm{O}$ that suppresses reduction rate the most. The mechanisms and kinetics of the reduction of $\mathrm{Zn}-\mathrm{Ti}-\mathrm{O}$ solids were studied and compared with that of single $\mathrm{ZnO}$ to elucidate the role of titanium oxide in reduction. Only reduction by $\mathrm{H}_{2}$ was investigated. From the studies of others (Grunze and Hirschwald, 1974), reduction of $\mathrm{ZnO}$ in $\mathrm{H}_{2}$ is faster than in $\mathrm{CO}$. Thus, the reduction rates obtained with $\mathrm{H}_{2}$ represent the maximum amount of zinc loss possible in a coal gas atmosphere. In addition, the effect of $\mathrm{H}_{2} \mathrm{O}$ on the rate of reduction was examined since $\mathrm{H}_{2} \mathrm{O}$ is a major component in coal gases, and has been reported (Hegedus and Kiss, 1966; FlytzaniStephanopoulos et al., 1987) to inhibit the reduction of $\mathrm{ZnO}$. The effect of $\mathrm{H}_{2} \mathrm{~S}$ on reduction was also investigated.

\section{EXPERIMENTAL METHODS}

\section{Preparation and characterization of solids}

Bulk mixed oxide solids of zinc and titanium were prepared by a known method for synthesizing highly dispersed mixed oxides from amorphous citrate precursors (Marcilly et al., 1970; Courty et al., 1973). The preparation of $\mathbf{Z n}-\mathrm{Ti}$ oxides consists of slowly adding a 2:1 volume ratio solution of glacial acetic acid (Mallinckrodt, AR grade) and titanium(IV) isopropoxide (Strem Chemicals, AR grade) to an aqueous solution of zinc acetate (Mallinckrodt, AR grade) and citric acid monohydrate (Mallinckrodt, AR grade) under constant agitation. Typically, an equal mole ratio of citric acid to metal ions (zinc and titanium) is used in preparing the solution. The final solution is first dehydrated rapidly $(15-30 \mathrm{~min})$ in a rotaryvacuum evaporator at $65-75^{\circ} \mathrm{C}$ to form a viscous liquid and then dehydrated slowly $(4-6 \mathrm{~h})$ in a vacuum oven at $70-80^{\circ} \mathrm{C}$ to form a porous solid foam. The solid foam was calcined in air in a muffle furnace at $720^{\circ} \mathrm{C}$ for $12 \mathrm{~h}$, producing a porous, homogeneous mixed metal oxide.

The solids were characterized by several bulk and surface analysis techniques. The elemental composition (zinc and titanium) of the solids was verified by atomic absorption spectroscopy (Perkin Elmer 360 Spectrophotometer) of the solids dissolved in a hot $\mathrm{HF}-\mathrm{HCl}-\mathrm{H}_{2} \mathrm{O}$ solution $\left(\sim 90^{\circ} \mathrm{C}\right)$. X-ray difiraction (XRD) for identification of crystalline phases in the mixed oxides was performed with a Rigaku RU300 instrument using $\mathbf{C u}(\mathrm{K} \alpha)$ radiation. Scanning electron microscopy (SEM) with a Cambridge Stereoscan $250 \mathrm{MK} 3$ instrument was used to observe the surface morphology and crystallite size of the solids. Surface areas were measured by a Micromeritics Flow Sorb III 2300 BET apparatus using $\mathbf{N}_{2}$ gas.

\section{Apparatus and procedure}

Kinetic reduction experiments with solids containing various $\mathrm{Zn} / \mathrm{Ti}$ atomic ratios were performed in a
Cahn System 113-X thermogravimetric analyzer (TGA) equipped with a Cahn 2000 electrobalance, a Micricon temperature controller, and a Bascom-Turner data acquisition system. The TGA reactor system is shown in Fig. 1. The TGA measured the weight loss as a function of the time required for the reduction of $\mathrm{Zn}-\mathrm{Ti}$ oxides to $\mathrm{Zn}$ and $\mathrm{TiO}_{2}$, followed by rapid zinc vaporization. The chemical and physical properties of the solids used in reduction experiments are shown in Table 1 . To ensure that the rate measurements were taken in the absence of gas phase diffusion limitation or equilibrium limitation, small amounts (1-2 mg) of material were used in each test and several samples were sintered at $1000^{\circ} \mathrm{C}$ for $1 \mathrm{~h}$ to minimize their surface area. In addition, the gas-flow rate was varied to ensure the absence of diffusional limitation.

Gas-flow rates were set by passing the $\mathrm{H}_{2}$ and $\mathrm{N}_{2}$ gases through Brooks Model 5850E mass-flow controllers. A gas flow rate of $485 \mathrm{~cm}^{3} \mathrm{~min}^{-1}$ (STP) was used in the experiments. Water vapor was added to the gas by bubbling nitrogen and hydrogen through a water saturator, maintained at either 25 or $51^{\circ} \mathrm{C}$ in a three-neck flask assembly. Calibration of the saturator was performed gravimetrically by measuring the weight change in a bed of Drierite placed downstream of the saturator. The saturated gas stream entered the apparatus side arm through heated lines. A thin layer of solid particles ( $\sim 1 \mathrm{mg}$ and $90-125 \mu \mathrm{m}$ size) was placed on a quartz pan suspended by a quartz hangdown wire. Isothermal reduction experiments were performed at temperatures between 550 and $1050^{\circ} \mathrm{C}$. Each solid was pretreated in a vacuum oven at $90^{\circ} \mathrm{C}$ for $1 \mathrm{~h}$ to remove any absorbed $\mathrm{H}_{2} \mathrm{O}$ before it was reacted in the TGA.

It was not possible to directly examine the effect of hydrogen sulfide on reduction since in addition to reduction, sulfidation would also occur. To separate these effects, the solids were first partially sulfided $(10-15 \%)$ in $2 \mathrm{~mol} \% \mathrm{H}_{2} \mathrm{~S}-1 \mathrm{~mol} \% \mathrm{H}_{2}-97 \mathrm{~mol} \% \mathrm{~N}_{2}$ and then reduced in $10 \mathrm{~mol} \% \mathrm{H}_{2}-90 \mathrm{~mol} \% \mathrm{~N}_{2}$.

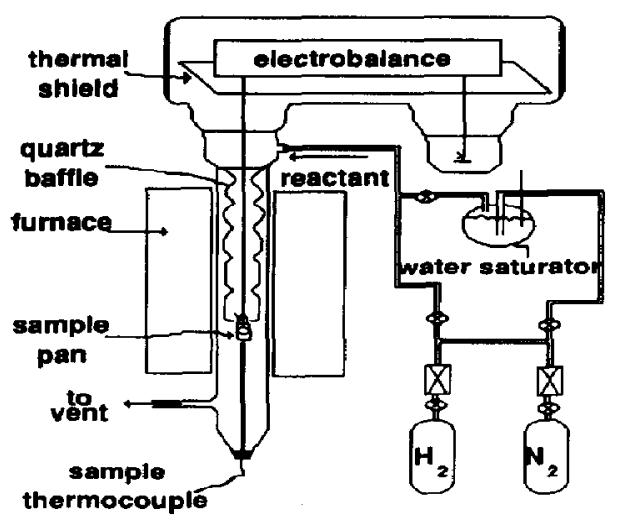

X] mass flowmeter

Fig. 1. Schematic of the thermobalance reactor system. 
Table 1. Chemical and physical properties of solids used in reduction experiments ${ }^{t}$

\begin{tabular}{|c|c|c|c|c|c|c|c|c|}
\hline \multirow[b]{2}{*}{ Sorbent } & \multirow{2}{*}{$\begin{array}{l}\mathrm{Zn} / \mathrm{Ti} \\
\text { (atomic } \\
\text { ratio) }\end{array}$} & \multirow{2}{*}{$\begin{array}{c}\text { Calcination } \\
\text { temperature } \\
\left({ }^{\circ} \mathrm{C}\right)\end{array}$} & \multirow{2}{*}{$\begin{array}{c}\text { Surface } \\
\text { area } \\
\left(\mathrm{m}^{2} / \mathrm{g}\right)\end{array}$} & \multicolumn{5}{|c|}{ Crystalline phases (wt \%) } \\
\hline & & & & $\mathrm{ZnO}$ & $\mathrm{Zn}_{2} \mathrm{TiO}_{4}$ & $\mathrm{Zn}_{2} \mathrm{Ti}_{3} \mathrm{O}_{8}$ & $\mathrm{ZnTiO}_{3}$ & $\mathrm{TiO}_{2}$ \\
\hline $\begin{array}{l}\text { ZnO } \\
\text { Z9T } \\
\text { Z3T } \\
\text { Z2T } \\
\text { Z3T2 } \\
\text { ZT-a } \\
\text { ZT-b } \\
\text { Z2T3-a } \\
\text { Z2T3-b }\end{array}$ & $\begin{array}{l}\overline{9 / 1} \\
3 / 1 \\
2 / 1 \\
3 / 2 \\
1 / 1 \\
1 / 1 \\
2 / 3 \\
2 / 3\end{array}$ & $\begin{array}{c}1000,1 \mathrm{~h} \\
1000,1 \mathrm{~h} \\
1000,1 \mathrm{~h} \\
1000,1 \mathrm{~h} \\
720,12 \mathrm{~h} \\
1000,1 \mathrm{~h} \\
720,12 \mathrm{~h} \\
720,12 \mathrm{~h} \\
700,12 \mathrm{~h}\end{array}$ & $\begin{array}{l}0.68 \\
1.03 \\
0.94 \\
0.76 \\
2.18 \\
0.40 \\
1.64 \\
2.29 \\
1.30\end{array}$ & $\begin{array}{r}100 \\
70 \\
25 \\
0 \\
0 \\
0 \\
0 \\
0 \\
0\end{array}$ & $\begin{array}{r}0 \\
30 \\
75 \\
100 \\
68 \\
75 \\
20 \\
0 \\
0\end{array}$ & $\begin{array}{r}0 \\
0 \\
0 \\
0 \\
14 \\
0 \\
35 \\
16 \\
0\end{array}$ & $\begin{array}{r}0 \\
0 \\
0 \\
0 \\
18 \\
0 \\
45 \\
65 \\
83\end{array}$ & $\begin{array}{r}0 \\
0 \\
0 \\
0 \\
0 \\
25 \\
0 \\
19 \\
17\end{array}$ \\
\hline
\end{tabular}

Teduction experiments performed with 90-125 $\mu \mathrm{m}$ particles.

* Sorbents calcined at $1000^{\circ} \mathrm{C}$ were first calcined at $720^{\circ} \mathrm{C}$ for $12 \mathrm{~h}$.

Calcined in the absence of air flow (static conditions).

Sulfidation and reduction were performed at the same temperature.

\section{RESULTS AND DISCUSSION}

Initial reduction rate of bulk $\mathrm{Zn}-\mathrm{Ti}-\mathrm{O}$ solids in hydrogen-nitrogen mixtures

Initial rate experiments in the TGA were performed under isothermal conditions to determine the reduction reactivity of solids containing various atomic ratios of $\mathrm{Zn}$ : $\mathrm{Ti}$ and various chemical phases (i.e. $\mathrm{ZnO}$, $\mathrm{Zn}_{2} \mathrm{TiO}_{4}, \mathrm{ZnTiO}_{3}$ and $\mathrm{Zn}_{2} \mathrm{Ti}_{3} \mathrm{O}_{8}$ ). Kinetic parameters were determined from these experiments. The possible overall reduction reactions are

$$
\begin{aligned}
& \mathrm{ZnO}(\mathrm{s})+\mathrm{H}_{2}(\mathrm{~g}) \rightarrow \mathrm{Zn}(\mathrm{g})+\mathrm{H}_{2} \mathrm{O}(\mathrm{g}) \\
& 1 / 2 \mathrm{Zn}_{2} \mathrm{TiO}_{4}(\mathrm{~s})+\mathrm{H}_{2}(\mathrm{~g}) \rightarrow \mathrm{Zn}(\mathrm{g}) \\
& \quad+\mathrm{H}_{2} \mathrm{O}(\mathrm{g})+1 / 2 \mathrm{TiO}_{2}(\mathrm{~s}) \\
& \mathrm{ZnTiO}_{3}+\mathrm{H}_{2}(\mathrm{~g}) \rightarrow \mathrm{Zn}(\mathrm{g})+\mathrm{H}_{2} \mathrm{O}(\mathrm{g})+\mathrm{TiO}_{2}(\mathrm{~s}) \\
& 1 / 2 \mathrm{Zn}_{2} \mathrm{Ti}_{3} \mathrm{O}_{8}+\mathrm{H}_{2}(\mathrm{~g}) \rightarrow \mathrm{Zn}(\mathrm{g}) \\
& \quad+\mathrm{H}_{2} \mathrm{O}(\mathrm{g})+3 / 2 \mathrm{TiO}_{2}(\mathrm{~s}) \\
& 3 \mathrm{TiO}_{2}(\mathrm{~s})+\mathrm{H}_{2}(\mathrm{~g}) \rightarrow \mathrm{Ti}_{3} \mathrm{O}_{5}(\mathrm{~s})+\mathrm{H}_{2} \mathrm{O}(\mathrm{g}) .
\end{aligned}
$$

To determine whether any reduction of $\mathrm{TiO}_{2}$ occurs by reaction (5), both rutile (UCI 1090-113 extrusions crushed to 90-125 $\mu \mathrm{m}$ size particles) and anatase (obtained from Aldrich Chemical Co. in white powder form, $99.9 \%$ pure) were reacted with $\mathrm{H}_{2}$ at $700-1000^{\circ} \mathrm{C}$. The reduction of $\mathrm{TiO}_{2}$ in hydrogen at elevated temperatures can be observed by a change in color from white to bluish gray (Matsuda and Kato, 1983) due to the formation of $\mathrm{Ti}_{3} \mathrm{O}_{5}$. No weight change of either crystalline form of $\mathrm{TiO}_{2}$ was observed after $60 \mathrm{~min}$ in $10 \mathrm{~mol} \% \mathrm{H}_{2}-90 \mathrm{~mol} \% \mathrm{~N}_{2}$ at each temperature of 700,800 or $1000^{\circ} \mathrm{C}$. The color of $\mathrm{TiO}_{2}$ changed to gray only after the experiment at $1000^{\circ} \mathrm{C}$, indicating that surface reduction of $\mathrm{TiO}_{2}$ took place under these conditions.

The initial reduction rate of various $\mathrm{Zn}-\mathrm{Ti}-\mathrm{O}$ materials listed in Table 1 was measured in $10 \mathrm{~mol} \%$ $\mathrm{H}_{2}-90 \mathrm{~mol} \% \mathrm{~N}_{2}$. The initial rate was calculated by:

$$
R_{\mathrm{o}}=\frac{(\mathrm{d} W / \mathrm{d} t)_{\mathrm{t}=0}}{(81.3794) A_{\mathrm{o}}}
$$

where the initial rate is $R_{0}\left(\mathrm{mmol} \mathrm{cm} \mathrm{cm}^{-2} \mathrm{~s}^{-1}\right)$, $(\mathrm{d} W / \mathrm{dt})_{t=0}\left(\mathrm{mg} \mathrm{s}^{-1}\right)$ is the slope of the weight vs time profile at $t=0,81.3794$ is the molecular weight of $\mathrm{ZnO}$, and $A_{0}\left(\mathrm{~cm}^{2}\right)$ is the initial surface area of the reactant solid. Comparative plots of the initial reduction rates of solids containing various $\mathrm{Zn} / \mathrm{Ti}$ atomic ratios reacted at 600 and $700^{\circ} \mathrm{C}$ are shown in Fig. 2 . At both 600 and $700^{\circ} \mathrm{C}$, the rate of reduction of $\mathrm{ZnO}$ was greater than that of any of the $\mathrm{Zn}-\mathrm{Ti}-\mathrm{O}$ solids. With as little as $10 \mathrm{~mol}^{\%} \mathrm{TiO}_{2}$ (sorbertt Z9T), there was still a significant (twofold) decrease in the rate of $\mathrm{ZnO}$ reduction. The reduction rate of $\mathrm{ZnO}$ was about 13 times greater than that of $\mathrm{Zn}-\mathrm{Ti}-\mathrm{O}$ solids with $(\mathrm{Zn} / \mathrm{Ti})_{\text {atomic }} \leqslant 3$ at $600^{\circ} \mathrm{C}$ and ten times greater at $700^{\circ} \mathrm{C}$. When the relative amount of $\mathrm{TiO}_{2}$ was increased above $25 \mathrm{~mol} \%$, no significant change in the reduction rate was observed. This implied that the presence of different zinc titanate phases had no significant effect on reduction. For example, the solid Z2T $(2 \mathrm{Zn} / 1 \mathrm{Ti})$ which contained only the crystalline phase $\mathrm{Zn}_{2} \mathrm{TiO}_{4}$ had approximately the same reduction rate as the solid Z2T3-b, which contained a mixture of $\mathrm{ZnTiO}_{3}$ and $\mathrm{TiO}_{2}$. Also the sorbents Z2T3-a (containing $\mathrm{Zn}_{2} \mathrm{Ti}_{3} \mathrm{O}_{8}, \mathrm{ZnTiO}_{3}$ and $\mathrm{TiO}_{2}$ ) and $\mathrm{Z2T3-b}$ (containing $\mathrm{ZnTiO}_{3}$ and $\mathrm{TiO}_{2}$ ) gave similar initial reduction rates. This finding simplified the testing because it eliminated the need to prepare pure zinc titanate phases of the type $\mathrm{Zn}_{2} \mathrm{Ti}_{3} \mathrm{O}_{8}$ or $\mathrm{ZnTiO}_{3}$ which were hard to obtain. Often, mixtures of these phases were formed.

In order to elucidate the mechanism by which the presence of titanium in the solid inhibits $\mathrm{ZnO}$ reduction, further kinetic experiments were performed. In the absence of both diffusional and external mass transfer resistances, an intrinsic initial heterogeneous rate expression of the form

$$
\boldsymbol{R}_{\mathrm{0}}=\boldsymbol{k} \boldsymbol{C}_{\mathbf{H}_{2}}^{\boldsymbol{n}_{2}}
$$

was used, where $k$ is the intrinsic rate constant, $\mathrm{C}_{\mathrm{H}_{2}}$ is the molar concentration $\left(\mathrm{mmol} \mathrm{cm}^{-3}\right)$ of hydrogen 


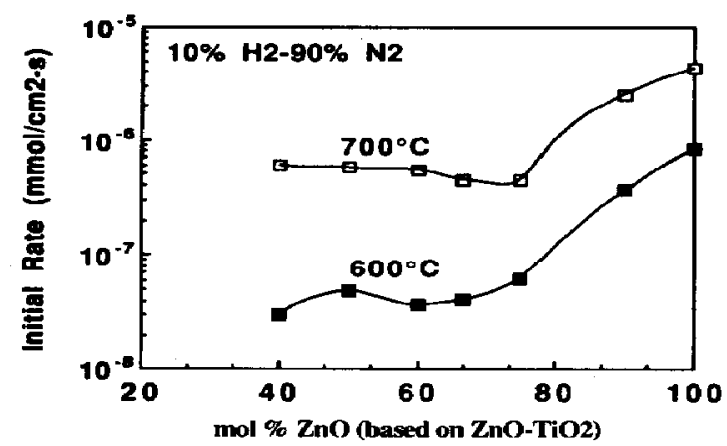

Fig. 2. Comparative plots of the initial reduction rate of various $\mathrm{Zn}-\mathrm{Ti}-\mathrm{O}$ materials reacted at 600 and $700^{\circ} \mathrm{C}$ in $10 \% \mathrm{H}_{2}-90 \% \mathrm{~N}_{2}$.

gas, and $n$ is the reaction order. The reaction order of $\mathrm{ZnO}$ and $\mathrm{Z} 2 \mathrm{~T}$ reduction was determined by varying the hydrogen gas concentration at $700^{\circ} \mathrm{C}$ as shown in Fig. 3. At $700^{\circ} \mathrm{C}$, the reaction order obtained for $\mathrm{ZnO}$ was 0.51 , while that of $\mathrm{Z} 2 \mathrm{~T}$ was one. The former result is in agreement with the work of Grunze and Hirschwald $(1974,1975)$ where fractional reaction orders for $\mathrm{ZnO}$ reduction were also observed. At $700^{\circ} \mathrm{C}$ and for pressure in the range of 1-4 torr, a reaction order of 0.60 was reported in that work.

The reaction rate constant can be expressed by an Arrhenius relationship, thus defining an activation energy:

$$
k=k_{0} \exp (-E / R T)
$$

where $k_{\mathrm{v}}\left(\mathrm{mmol}^{1-n} \mathrm{~cm}^{-3 n+2} \mathrm{~s}^{-1}\right)$ is a constant, $E$ is the activation energy, $R$ is the ideal gas constant, and $T$ is the absolute temperature. Because of the difference in reaction order between $\mathrm{ZnO}$ and $\mathrm{Z} 2 \mathrm{~T}$ it is not possible to directly compare the Arrhenius plots of $\mathrm{ZnO}$ and Z2T. To facilitate the comparison of $\mathrm{ZnO}$ and Z2T, Arrhenius-type plots are drawn in terms of initial rate vs $1 / T$. However, the activation energy and $k_{0}$ were calculated by eq. (8). Figure 4 shows the initial reduction rates of $\mathrm{ZnO}$ and $\mathrm{Z2T}$ on Arrhenius plots. At all temperatures $\left(550-1050^{\circ} \mathrm{C}\right)$, the rate of reduction of $\mathrm{ZnO}$ was faster than that of $\mathrm{Z2T}$. Based on eq. 8 , an activation energy of $24.0 \mathrm{kcal} \mathrm{mol}^{-1}$ and $k_{0}$ of $27.5 \mathrm{mmol}^{0.49} \mathrm{~cm}^{-0.47} \mathrm{~s}^{-1}$ were obtained for reduction in $10 \mathrm{~mol} \% \mathrm{H}_{2}-90 \mathrm{~mol} \% \mathrm{~N}_{2}$. This activation energy was close to the values $\left(27-28 \mathrm{kcal} \mathrm{mol}^{-1}\right)$ reported by others for temperatures up to $700^{\circ} \mathrm{C}$ for ZnO powders (Hegedus and Kiss, 1966; Grunze and Hirschwald, 1974, 1975). For Z2T, the activation energy was $37.3 \mathrm{kcal} \mathrm{mol}^{-1}$ and $k_{0}$ was $6.3 \times 10^{4} \mathrm{~cm} \mathrm{~s}^{-1}$.

Figure 5 shows that the initial reduction rates of various $\mathrm{Zn}-\mathrm{Ti}-\mathrm{O}$ materials with $(\mathrm{Zn} / \mathrm{Ti})_{\text {atomic }} \leqslant 3$ are similar to that of the sorbent Z2T. The solid Z9T, on the other hand, behaves like ZnO. Figure 6 shows the Arrhenius-type plots of the initial reduction rates of $\mathrm{ZnO}$ and Z9T. The activation energy for Z9T was $24.7 \mathrm{kcal} \mathrm{mol}^{-1}$, similar to the value obtained for ZnO. This indicated that the same reaction mechanism was involved in the reduction of $\mathrm{ZnO}$ and $\mathrm{Z9T}$,

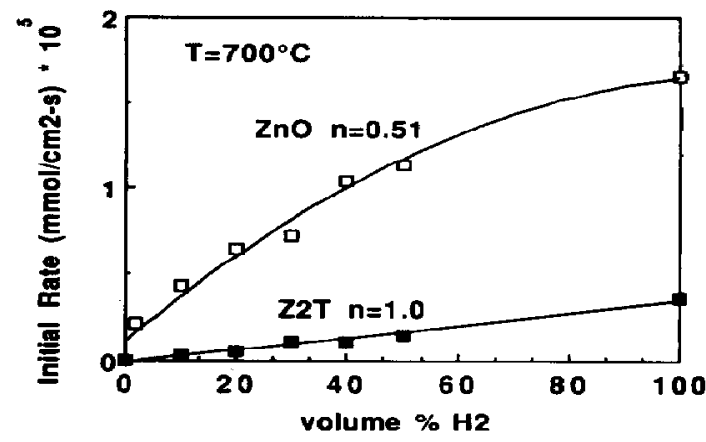

Fig. 3. Effect of hydrogen concentration on the initial reduction rate of $\mathrm{ZnO}$ and $\mathrm{Z} 2 \mathrm{~T}$ at $700^{\circ} \mathrm{C}$.

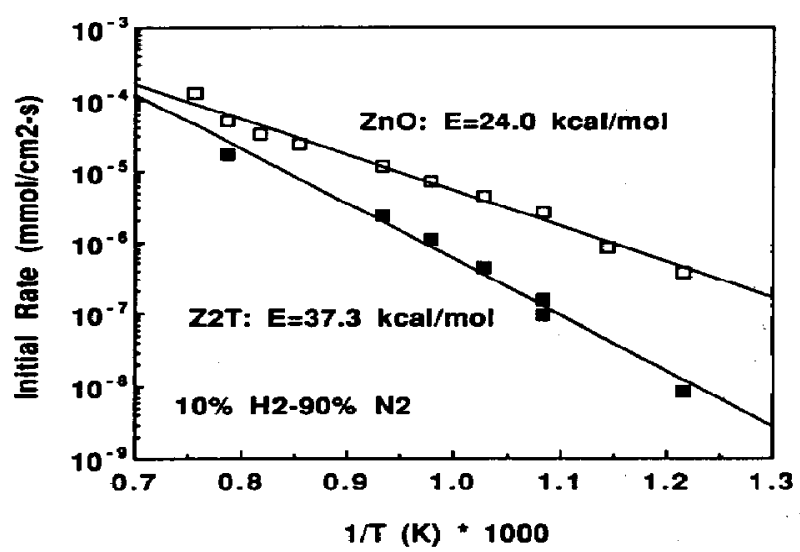

Fig. 4. Arrhenius-type plots of the initial reduction rates of $\mathrm{ZnO}$ and Z2T. Activation energies were calculated by eq. (8).

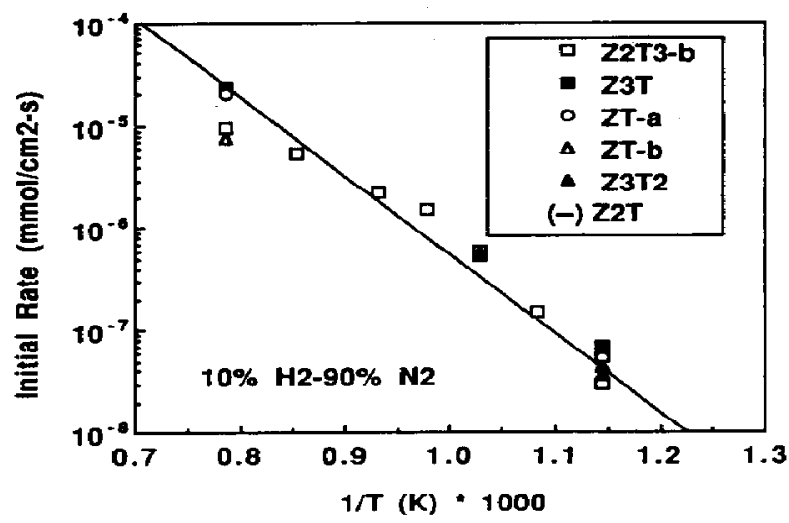

Fig. 5. Arrhenius-type plots of the initial reduction rates of various $\mathrm{Zn}-\mathrm{Ti}-\mathrm{O}$ solids.

which is not surprising considering that $\mathrm{Z9T}$ is comprised of $70 \mathrm{wt} \% \mathrm{ZnO}$ and $30 \mathrm{wt} \% \mathrm{Zn}_{2} \mathrm{TiO}_{4}$ as identified by XRD (Table 1). The major difference between $\mathrm{ZnO}$ and $\mathrm{Z9T}$ was the constant $k_{0}$. For $\mathrm{ZnO}, k_{0}$ was $27.5 \mathrm{mmol}^{0.49} \mathrm{~cm}^{-0.47} \mathrm{~s}^{-1}$, while for $Z 9 \mathrm{~T}$ it was $17.4 \mathrm{mmol}^{0.49} \mathrm{~cm}^{-0.47} \mathrm{~s}^{-1}$. 


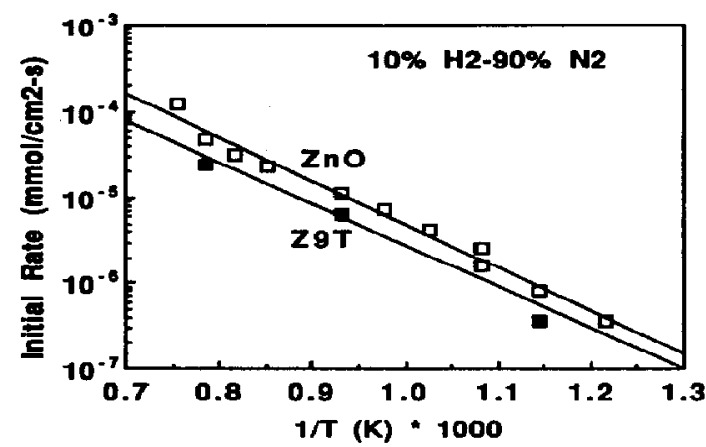

Fig. 6. Arrhenius-type plots of the initial reduction rates of $\mathrm{ZnO}$ and $\mathrm{Z9T}$.

Initial reduction rate of bulk $\mathrm{Zn}-\mathrm{Ti}-\mathrm{O}$ sorbents: effect of water vapor

Various amounts of water vapor were added to the reducing gas to identify potential inhibitory effects on the reduction rate. For $\mathrm{ZnO}$, a dramatic effect of $\mathrm{H}_{2} \mathrm{O}$ on the reduction rate was observed with a concomitant change in the reaction order. Figure 7 shows the Arrhenius plots of $\mathrm{ZnO}$ reduction in the presence of various amounts of water vapor. The inclusion of $1 \mathrm{~mol} \% \mathrm{H}_{2} \mathrm{O}$ in the gas significantly decreased the reduction rate of $\mathrm{ZnO}$. However, when the amount of water vapor was increased to 3 or $8 \mathrm{~mol} \%$, the reduction rate did not decrease any more. Figure 8 shows the effect of $\mathrm{H}_{2}$ concentration on the initial reduction rate of $\mathrm{ZnO}$ and $\mathrm{Z2T}$ in the presence of $3 \mathrm{~mol} \% \mathrm{H}_{2} \mathrm{O}$ at $700^{\circ} \mathrm{C}$. The reaction order for $\mathrm{ZnO}$ changed to one from its value of 0.51 in the absence of $\mathrm{H}_{2} \mathrm{O}$. In contrast, the reaction rate of $\mathrm{Z} 2 \mathrm{~T}$ remained first order. The activation energy was significantly higher in the presence of water vapor. With a gas containing $10 \mathrm{~mol} \% \mathrm{H}_{2}-3 \mathrm{~mol} \% \mathrm{H}_{2} \mathrm{O}-87 \mathrm{~mol} \% \mathrm{~N}_{2}$, the activation energy was $43.9 \mathrm{kcal} \mathrm{mol}^{-1}$ and $k_{0}$ was 9.27 $\times 10^{5} \mathrm{~cm} \mathrm{~s}^{-1}$. In contrast, the activation energy was only $24.0 \mathrm{kcal} \mathrm{mol}^{-1}$ for the dry reduction.

Water also had an inhibitory effect on the reduction of $\mathrm{Zn}-\mathrm{Ti}-\mathrm{O}$ solids. Figure 9 shows the Arrhenius plots of $\mathrm{Z} 2 \mathrm{~T}$ reduction in the presence of 0,3 and $8 \mathrm{~mol} \% \mathrm{H}_{2} \mathrm{O}$. However, the water vapor affected the reduction kinetics of Z2T less than that of $\mathrm{ZnO}$. The activation energy increased form 37.3 to $44.0 \mathrm{kcal}$ $\mathrm{mol}^{-1}$ and $k_{0}$ changed to $3.36 \times 10^{5} \mathrm{~cm} \mathrm{~s}^{-1}$. The new activation energy was approximately the same as the value obtained for $\mathrm{ZnO}$ reduction $\left(43.9 \mathrm{kcal} \mathrm{mol}^{-1}\right)$ in the pesence of $3 \mathrm{~mol} \% \mathrm{H}_{2} \mathrm{O}$. The only difference was that the pre-exponential factor, $k_{0}$, for Z2T was 2.8 times smaller than that of ZnO. No effect on the reduction of Z2T was observed when a gas mixture with higher $\mathrm{H}_{2} \mathrm{O}$ content $(8 \mathrm{~mol} \%)$ was used, similar to the results for $\mathrm{ZnO}$.

Similar inhibitory effects on $\mathrm{ZnO}$ reduction by water vapor have been observed by others (Hegedus and Kiss, 1966; Flytzani-Stephanopoulos et al., 1987). From thermogravimetric studies, Hegedus and Kiss (1966) observed that as the water vapor content in a

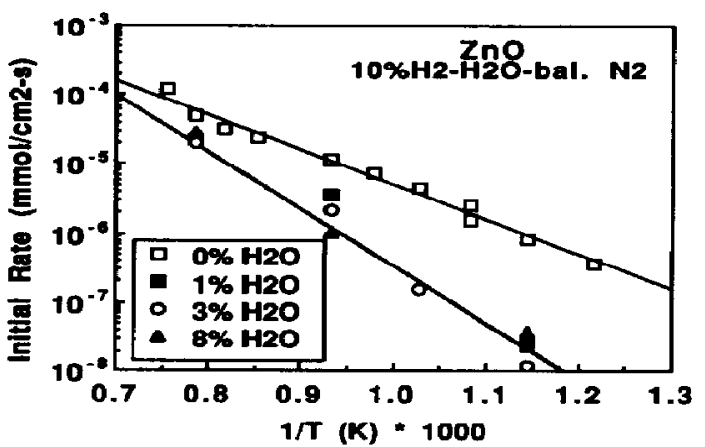

Fig. 7. Arrhenius-type plots of the initial reduction rates of $\mathrm{ZnO}$ in the presnce of various amounts of $\mathrm{H}_{2} \mathrm{O}$.

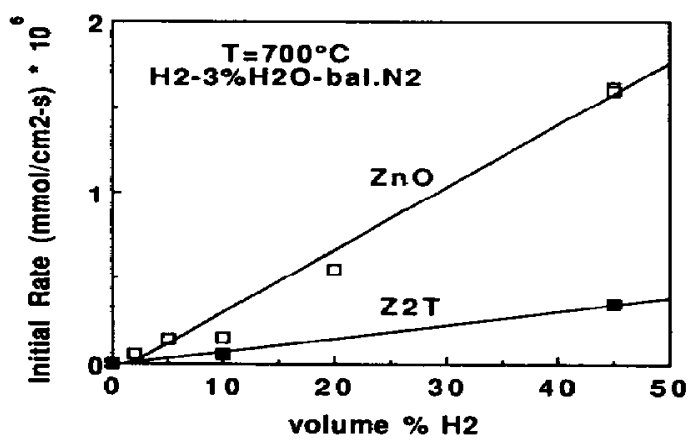

Fig. 8. Effect of hydrogen concentration on the initial reduction rate of $\mathrm{ZnO}$ and $\mathrm{Z} 2 \mathrm{~T}$ in the presence of $3 \% \mathrm{H}_{2} \mathrm{O}$ at $700^{\circ} \mathrm{C}$.

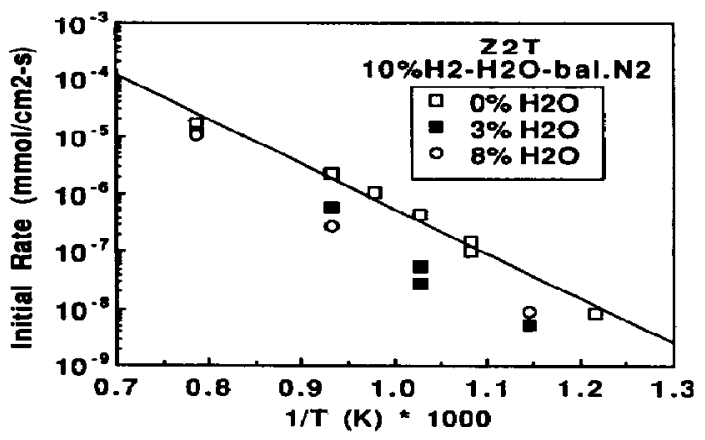

Fig. 9. Arrhenius-type plots of the initial reduction rates of Z2T in the presence of various amounts of $\mathrm{H}_{2} \mathrm{O}$.

flowing stream of hydrogen increased from 7.0 $\times 10^{-3} \%$ (0.053 torr) to $5.9 \times 10^{-2} \%$ (0.45 torr), the activation energy for $\mathrm{ZnO}$ reduction increased from 27.4 to $52 \mathrm{kcal} \mathrm{mol}^{-1}$. Correspondingly, as the amount of water vapor was increased, the reduction rate decreased. However, when the amount of $\mathrm{H}_{2} \mathrm{O}$ was increased further to $2.1 \%$ (16.2 torr), no further change in the activation energy was observed. Flytzani-Stephanopoulos et al. (1987) also observed lower reduction rates for zinc oxide as well as zinc titanates in the presence of $\mathrm{H}_{2} \mathrm{O}$ vapor. 
A comparative plot of the initial reduction rates of various $\mathrm{Zn}-\mathrm{Ti}-\mathrm{O}$ materials at $700^{\circ} \mathrm{C}$ in $10 \mathrm{~mol} \% \mathrm{H}_{2}-$ $3 \mathrm{~mol} \% \mathrm{H}_{2} \mathrm{O}-87 \mathrm{~mol} \% \mathrm{~N}_{2}$ is shown in Fig. 10. The reduction rates of $\mathrm{Zn}-\mathrm{Ti}-\mathrm{O}$ solids were lower than for bulk $\mathrm{ZnO}$. The reduction rate steadily decreased as the relative amount of $\mathrm{TiO}_{2}$ in the solid was increased. Unlike the dry reduction resutls (Fig. 2), no plateau is shown in Fig. 10 for solids with $(\mathrm{Zn} / \mathrm{Ti})_{\text {atomic }} \leqslant 3$. Comparative Arrhenius plots of ZnO, Z2T and Z2T3$b$ in the presence of $\mathrm{H}_{2} \mathrm{O}$ are shown in Fig. 11. The activation energies of all solids were approximately the same $\left(\sim 44 \mathrm{kcal} \mathrm{mol}^{-1}\right)$. The difference in reactivity lies in the pre-exponential constant, $k_{0}$, as listed in Table 2. For Z2T3-b, the value of $k_{0}$ was 7.1 times smaller than for $\mathrm{ZnO}$.

In an earlier paper (Lew et al., 1989) dry reduction of higher surface area solids (e.g. $\mathrm{ZnO}: 2.4 \mathrm{~m}^{2} \mathrm{~g}^{-1}$ ) was reported to occur at rates lower (by tenfold) than that in this work. The self-inhibitory effect produced by the larger product $\mathrm{H}_{2} \mathrm{O}$ concentrations in the earlier study can explain the lower reported values of reduction rates. Hegedus and Kiss (1966) observed a decrease in the reduction rate as the mole fraction of $\mathrm{H}_{2} \mathrm{O}$ was varied from $7.0 \times 10^{-3}$ to $5.9 \times 10^{-2 \%} \%$. In our previous work, the product $\mathrm{H}_{2} \mathrm{O}$ mole fraction was $6.5 \times 10^{-3} \%$ based on the rate of $\mathrm{H}_{2} \mathrm{O}$ production and the gas flow rate, while, in the present paper, the conditions of Fig. 2 correspond to $\mathrm{H}_{2} \mathrm{O}$ content of $1.3 \times 10^{-3} \mathrm{~mol} \%$. In addition, higher water vapor pressure may be found in porous materials of high surface area where small pores are prevalent. Reduction experiments in $\mathrm{H}_{2}-\mathrm{N}_{2}$ performed in this laboratory with $\mathrm{ZnO}$ single crystals characterized by low surface area $\left(8.2 \times 10^{-4} \mathrm{~m}^{2} \mathrm{~g}^{-1}\right)$ and zero porosity yielded similar initial reduction rate to the low surface area $\left(0.68 \mathrm{~m}^{2} \mathrm{~g}^{-1}\right)$ bulk $\mathrm{ZnO}$ solid reported here (Lew, 1990).

Initial reduction rate of $\mathrm{Zn}-\mathrm{Ti}-\mathrm{O}$ solids: effect of partial sulfidation

$\mathrm{ZnO}$ and $\mathrm{Z2T}$ were $10-15 \%$ sulfided between 600 and $700^{\circ} \mathrm{C}$ in $\mathrm{H}_{2}-\mathrm{H}_{2} \mathrm{~S}-\mathrm{N}_{2}$ gas mixtures. Subsequent reduction of the partially sulfided solids in $10 \mathrm{~mol} \%$ $\mathrm{H}_{2}-90 \mathrm{~mol} \% \mathrm{~N}_{2}$ showed a lower initial reduction rate

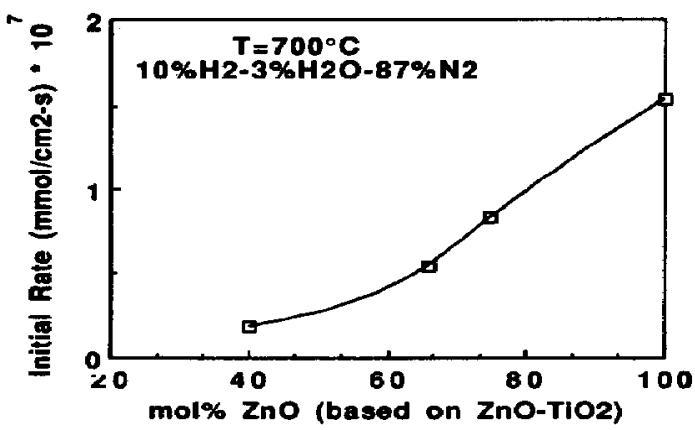

Fig. 10. A comparative plot of the initial reduction rates of various $\mathrm{Zn}-\mathrm{Ti}-\mathrm{O}$ materials reacted at $700^{\circ} \mathrm{C}$ in $10 \% \mathrm{H}_{2}-3 \%$ $\mathrm{H}_{2} \mathrm{O}-87 \% \mathrm{~N}_{2}$

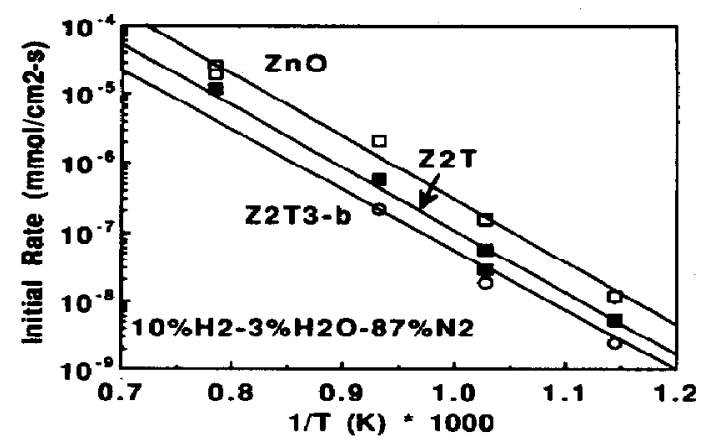

Fig. 11. Arrhenius-type plots of the initial reduction rates of $\mathrm{ZnO}, \mathrm{Z} 2 \mathrm{~T}$ and $\mathrm{Z} 2 \mathrm{~T} 3$ in $10 \% \mathrm{H}_{2}-3 \% \mathrm{H}_{2} \mathrm{O}-87 \% \mathrm{~N}_{2}$.

Table 2. Values of $k_{0}$ for solid reduction in the presence of $\mathrm{H}_{2} \mathrm{O}^{\dagger}$

\begin{tabular}{lc}
\hline Solid & $k_{\mathrm{o}}\left(\mathrm{cm} \mathrm{s}^{-1}\right)$ \\
\hline ZnO & $9.27 \times 10^{5}$ \\
Z2T & $3.36 \times 10^{5}$ \\
Z2T3-b & $1.31 \times 10^{5}$ \\
\hline
\end{tabular}

tArrhenius plots shown in

Fig. 11.

than reduction of the unsulfided solids. In these experiments, only the oxides were reduced. No reduction of $\mathrm{ZnS}$ was observed as measured by the weight change. As shown in Fig. 12, there appeared to be an inhibitory effect on reduction by $\mathrm{H}_{2} \mathrm{~S}$ similar to that found with water vapor. Figure 12 (b) shows the $\mathrm{ZnO}$ reduction profiles. A sigmoidal shape profile is found for $\mathrm{ZnO}$ which has been partially sulfided. Initially ( $<10 \mathrm{~min}$ ) the reduction profiles of partially sulfided $\mathrm{ZnO}$ and of $\mathrm{ZnO}$ reduced in the presence of $3 \% \mathrm{H}_{2} \mathrm{O}$ virtually overlap. As the reactant surface recedes from the sulfided layer, sites which are more reactive are exposed and a corresponding increase in rate is observed. The initial rates shown in Fig. 12(a) were measured from the early part of the reduction profiles. Because of some contribution from the more reactive sites and the small change in weight, the initial rate measurements for the partially sulfided solid tend to be on the high side and have some degree of error. In the following section, the reduction mechanism and the role of water vapor will be discussed. Hydrogen sulfide appears to play a role similar to that of water vapor.

\section{Reduction model}

From the kinetic measurements described above, a mechanism for $\mathrm{ZnO}$ reduction and inhibition by titanium dioxide can be proposed. For bulk ZnO, the inhibition pattern observed with water vapor suggests that two very different types of reaction sites are involved in reduction. The existence of multiple types of hydrogen chemisorption sites on the surface of $\mathrm{ZnO}$ at low temperatures $\left(<250^{\circ} \mathrm{C}\right.$ ) (Kesavulu and 


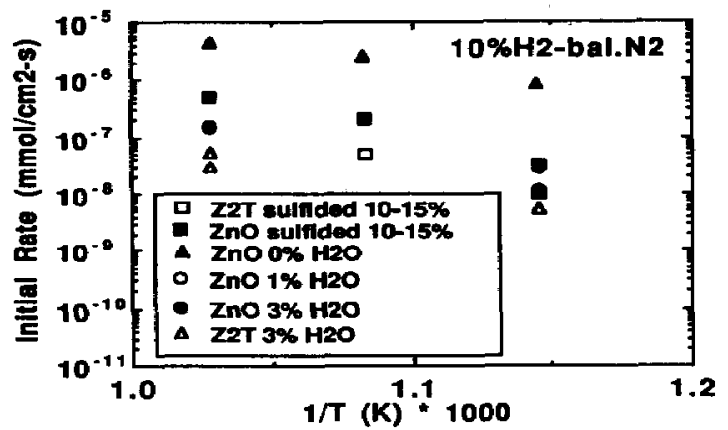

a)

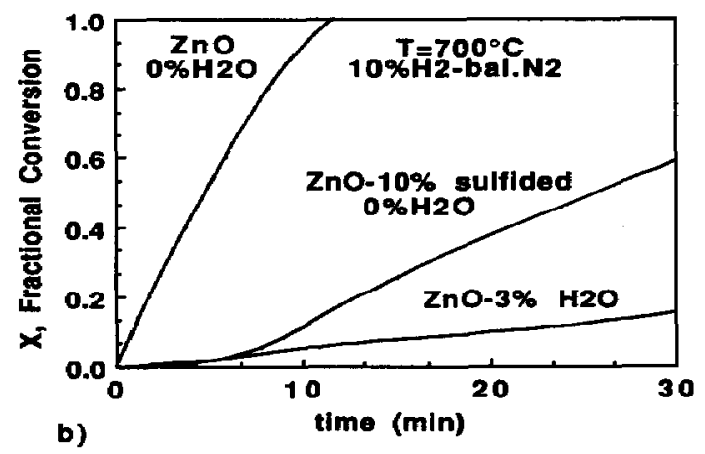

Fig. 12. Reduction of partially sulfided solids (a) comparison of the Arrhenius-type plots of the initial rate and (b) comparison of reduction profiles.

Taylor, 1960; Eischens et al., 1962; Dent and Kokes, 1969; Boccuzzi et al., 1978) has been reported in the literature. Since all the experiments performed in this study took place at much higher temperatures $\left(\geqslant 550^{\circ} \mathrm{C}\right.$ ) than the earlier chemisorption studies, it was not possible to directly extend the knowledge gained from those studies to the analysis of this system. However, the mechanistic insights gained from the previous work on $\mathrm{H}_{2}$ adsorption and $\mathrm{H}_{2} \mathrm{O}$ effects on different $\mathrm{ZnO}$ sites are also employed here.

For $\mathrm{ZnO}$ reduction at $550-1050^{\circ} \mathrm{C}$, two reaction sites are proposed. One type of sites, called type A, is characterized by a rapid reduction rate but is poisoned by water vapor. The other type of sites, called type $B$, has a slower reaction rate but is unaffected by $\mathrm{H}_{2} \mathrm{O}$. Since no change in the reduction rate is observed after a single monolayer has been reacted, it is assumed that the relative concentration of each type of sites is conserved in the successive monolayers. Each type of sites can be expressed in terms of a Langmuir-Hinshelwood equation. For type A sites, the following expression,

$$
R_{\mathrm{O}, A}=\frac{K_{A} C_{\mathrm{H}_{2}}}{\left(1+\sqrt{K_{\mathrm{H}_{2}, A} C_{\mathrm{H}_{2}}}+\sqrt{K_{\mathrm{H}_{2} \mathrm{O}, A} C_{\mathrm{H}_{2} \mathrm{O}}}\right)^{2}}
$$

is obtained, where $K_{A}$ is a constant related to the rate controlling step for the reaction, $K_{\mathrm{H}_{2}, A}$ and $K_{\mathrm{H}_{2} \mathrm{O}, A}$ are the hydrogen and water adsorption equilibrium constants on type A sites, respectively. From the apparent reaction order of $\mathrm{ZnO}$ reduction in the absence of $\mathrm{H}_{2} \mathrm{O}\left(n \sim 0.51\right.$ at $\left.700^{\circ} \mathrm{C}\right),\left(K_{\mathrm{H}_{2}, A} C_{\mathrm{H}_{2}}\right)^{0.5}$ must be the same order of magnitude as one. In the presence of $\mathrm{H}_{2} \mathrm{O}$, sites $A$ are poisoned. This is equivalent to $\left(K_{\mathrm{H}_{2} \mathrm{O}, \mathrm{A}} C_{\mathrm{H}_{2} \mathrm{O}}\right)^{0.5} \gg 1$ or $\left(K_{\mathrm{H}_{2}, \mathrm{~A}} C_{\mathrm{H}_{2}}\right)^{0.5}$. Thus, $R_{0, A}$ becomes small. For type $B$ sites, a similar Langmuir-Hinshelwood equation is obtained:

$$
R_{\mathrm{O}, \mathrm{B}}=\frac{K_{B} C_{\mathrm{H}_{2}}}{\left(1+\sqrt{K_{\mathrm{H}_{2}, B} C_{\mathrm{H}_{2}}}+\sqrt{K_{\mathrm{H}_{2} \mathrm{O}, \mathrm{B}} C_{\mathrm{H}_{2} \mathrm{O}}}\right)^{2}} .
$$

However, since the apparent reaction order of $\mathrm{ZnO}$ reduction in the presence of $\mathrm{H}_{2} \mathrm{O}$ was unity and there was no significant effect on the reduction rate when the amount of $\mathrm{H}_{2} \mathrm{O}$ was increased from 1 to $8 \mathrm{~mol} \%$, $\left(K_{\mathrm{H}_{2} . \mathrm{B}} C_{\mathrm{H}_{2}}\right)^{0.5}$ and $\left(K_{\mathrm{H}_{2} \mathrm{O} . \mathrm{B}} C_{\mathrm{H}_{2} \mathrm{O}}\right)^{0.5} \ll 1$. Consequently, eq. $(10)$ reduces to

$$
R_{\mathrm{O} . \mathrm{B}}=K_{\mathrm{B}} C_{\mathrm{H}_{2}} \text {. }
$$

The reaction rate is equal to the sum of the reactions on type $A$ and $B$ sites:

$$
R_{\mathrm{o}}=R_{\mathrm{o}, \mathrm{A}}+\boldsymbol{R}_{\mathrm{o,B}} \text {. }
$$

In the absence of $\mathrm{H}_{2} \mathrm{O}$, reactions on type $A$ sites is much faster than on type $B$ sites. Thus, $R_{0} \approx R_{0,1}$. At $700^{\circ} \mathrm{C}$ from the initial rates obtained at various hydrogen concentrations, the values of the constants are calculated and eq. (9) for $R_{0, A}$ becomes

$$
R_{0, A}=\frac{\left[1.27 \times 10^{-2}\left(\mathrm{~cm} \mathrm{~s}^{-1}\right)\right] C_{\mathrm{H}_{2}}}{\left[1+\sqrt{509.0\left(\mathrm{~cm}^{3} \mathrm{mmol}^{-1}\right) C_{\mathrm{H}_{2}}}\right]^{2}} .
$$

In the presence of $\mathrm{H}_{2} \mathrm{O}, R_{0, A} \approx 0$ and $R_{0} \approx R_{0 . B}$. For $\mathrm{ZnO}$ with the experimental results obtained with $10 \mathrm{~mol} \% \mathrm{H}_{2}-3 \mathrm{~mol} \% \mathrm{H}_{2} \mathrm{O}-87 \mathrm{~mol} \% \mathrm{~N}_{2}$, eq. (11) becomes

$$
\boldsymbol{R}_{\mathrm{O}, \mathrm{B}}=9.27 \times 10^{5}\left(\mathrm{~cm} \mathrm{~s}^{-1}\right) e^{-43.9\left(\mathrm{kcsl} \text { mol }{ }^{-1}\right) / R T} C_{\mathbf{H}_{2}} .
$$

For $\mathrm{Zn}-\mathrm{T}_{\mathbf{i}}-\mathrm{O}$ solids, the presence of titanium appears either to eliminate type A sites or modify their reactivity. The tenfold drop of the $\mathrm{ZnO}$ reduction rate in solids with $(\mathrm{Zn} / \mathrm{Ti})_{\text {atomic }} \leqslant 3$ at $700^{\circ} \mathrm{C}$ implies that type A sites are very sensitive to the presence of titanium. A solid (i.e. Z9T) with only $10 \mathrm{~mol} \% \mathrm{TiO}_{2}$ (based on $\mathrm{ZnO}-\mathrm{TiO}_{2}$ stoichiometry) has a reduction rate 1.7 times slower than the reduction rate of $\mathrm{ZnO}$ in the absence of $\mathrm{H}_{2} \mathrm{O}$. Because the activation energy for $\mathrm{Z9T}$ reduction is the same as for $\mathrm{ZnO}$ and only the pre-exponential factor is different, this suggests that titanium eliminates type A sites. Thus, titanium has a geometric effect on the reduction kinetics of $\mathrm{ZnO}$ rather than an electronic effect. If there is a simple linear relationship between the relative amount of titanium and the number of type A sites eliminated, based on the observed reduction rate of Z9T, all type A sites can be eliminated in a solid containing $24.3 \mathrm{~mol} \% \mathrm{TiO}_{2}$. Experimentally, no further decrease of the reduction rate was observed when the relative amount of titanium was above $25 \mathrm{~mol} \%$. Reduction of solids with $(\mathrm{Zn} / \mathrm{Ti})_{\text {atomic }} \leqslant 3$, therefore, probably proceeds on another type of sites, labelled $A^{\prime}$, which are not affected by the presence of titanium or the type of 
zinc titanate compound formed. Similar to A sites, however, $A^{\prime}$ sites are also poisoned by $\mathrm{H}_{2} \mathrm{O}$.

For $\mathrm{Zn}-\mathrm{Ti}-\mathrm{O}$ solids, in the absence of $\mathrm{H}_{2} \mathrm{O}$, the rate expession (9) for type $A^{\prime}$ sites becomes

$$
R_{\mathrm{O}}=6.30 \times 10^{4}\left(\mathrm{~cm} \mathrm{~s}^{-1}\right) e^{-37.3\left(\mathrm{kcm} \mathrm{mol} \mathrm{I}^{-1}\right) R T} C_{\mathrm{H}_{2}}
$$

In the presence of $\mathrm{H}_{2} \mathrm{O}$, both type $A$ and $\mathrm{A}^{\prime}$ sites are poisoned and reduction of $\mathrm{Zn}-\mathrm{Ti}-\mathrm{O}$ solids occurs by type $B$ sites. This conclusion is drawn because of the similar values of the activation energies of $\mathrm{Zn}-\mathrm{Ti}-\mathrm{O}$ and $\mathrm{ZnO}$ solids. The effect of titanium is to decrease the pre-exponential factor in the rate expression. As shown in Fig. 10, the reduction rate continued to decrease as the amount of titanium dioxide was increased from 0 to $60 \mathrm{~mol} \%$. Thus, the same rate expression as eq. (14) is found for the reduction of $\mathrm{Zn}-\mathrm{Ti}-\mathrm{O}$ solids in the presence of water vapor. However, the pre-exponential factor decreases as the amount of titanium dioxide in the solid increases. This is very different from the situation without $\mathrm{H}_{2} \mathrm{O}$ (Fig. 2), indicating that type $B$ sites are much less sensitive to the presence of titanium than type $A$ sites. Consequently, a higher relative amount of titanium is needed to obtain lower reduction rates. The difference in sensitivity between sites $A, A^{\prime}$ and $B$ may be explained geometrically by hypothesizing that type $A$ sites are composed of groups or ensembles of atoms. Earlier studies have reported a type of sites for $\mathrm{H}_{2}$ adsorption on $\mathrm{ZnO}$ consisting of a cluster of adjacent zinc cations and one oxygen anion (Boccuzzi et al., 1978; Griffin and Yates, 1982). The presence of titanium atoms in the cluster eliminates the activity of the site. The effect of titanium would be greatest on sites requiring the greatest number of nearby atoms. Consequently, type $A^{\prime}$ and $B$ sites must be composed of fewer atoms than type $A$ sites.

Reduction conversion profiles of bulk $\mathrm{Zn}-\mathrm{Ti}-\mathrm{O}$ solids

Typical experimental conversion-time profiles for $\mathrm{ZnO}$ and $\mathrm{Z} 2 \mathrm{~T}$ at $650^{\circ} \mathrm{C}$ are shown in Fig. 13. The following fractional conversion is defined as

$$
\boldsymbol{X}=\left(\boldsymbol{W}_{i}-W\right) /\left(\boldsymbol{W}_{i}-\boldsymbol{W}_{f}^{I}\right)
$$

where $W$ is the weight, $W_{i}$ is the initial weight, and $W_{f}^{I}$ is the final weight at complete conversion. For $\mathrm{ZnO}$, $W_{f}^{I}$ is equal to zero. $W_{f}^{I}$ is the weight of the remaining $\mathrm{TiO}_{2}$ for $\mathrm{Zn}-\mathrm{Ti}-\mathrm{O}$ solids. For both $\mathrm{ZnO}$ and $\mathrm{Z} 2 \mathrm{~T}$, the reaction rates remained relatively constant up to a high level of conversion. For Z2T reduction, a product layer of $\mathrm{TiO}_{2}$ is formed. Since the ratio of the solid product $\left(\mathrm{TiO}_{2}\right)$ molar volume to the solid reactant $\left(\mathrm{Zn}_{2} \mathrm{TiO}_{4}\right)$ molar volume is only 0.41 , a porous product layer is formed. Based on the conversion profiles, this product layer poses no hindrance to reaction.

To determine the chemical phase transformations of the $\mathrm{Zn}-\mathrm{Ti}-\mathrm{O}$ solids during reduction, partially reacted solids were examined by XRD. Sufficient quantities of materials for analyses were obtained by reacting $40-50 \mathrm{mg}$ of solids in the TGA. Table 3 lists the results of the XRD analyses of various partially reduced solids. The reactions were performed at $650^{\circ} \mathrm{C}$ in $10 \mathrm{~mol} \% \mathrm{H}_{2}-90 \mathrm{~mol} \% \mathrm{~N}_{2}$. For the solid $\mathrm{Z2T}$, the following reactions appeared to occur during reduction:

$$
\begin{aligned}
& \mathrm{Zn}_{2} \mathrm{TiO}_{4}(\mathrm{~s})+2 \mathrm{H}_{2}(\mathrm{~g}) \rightarrow 2 \mathrm{Zn}(\mathrm{g})+\mathrm{TiO}_{2}(\mathrm{~s}) \\
&+2 \mathrm{H}_{2} \mathrm{O}(\mathrm{g}) \\
& 1 / 2 \mathrm{Zn}_{2} \mathrm{TiO}_{4}(\mathrm{~s})+\mathrm{TiO}_{2}(\mathrm{~s}) \rightarrow 1 / 2 \mathrm{Zn}_{2} \mathrm{Ti}_{3} \mathrm{O}_{8}(\mathrm{~s}) \\
& \mathrm{Zn}_{2} \mathrm{Ti}_{3} \mathrm{O}_{8}(\mathrm{~s})+2 \mathrm{H}_{2}(\mathrm{~g}) \rightarrow 2 \mathrm{Zn}(\mathrm{g})+3 \mathrm{TiO}_{2}(\mathrm{~s}) \\
&+2 \mathrm{H}_{2} \mathrm{O}(\mathrm{g}) .
\end{aligned}
$$

No corresponding change in the reaction rate accompanied the phase change from $\mathrm{Zn}_{2} \mathrm{TiO}_{4}$ to $\mathrm{Zn}_{2} \mathrm{Ti}_{3} \mathrm{O}_{8}$. At conversion higher than $66 \%$, the only reactive phase present was $\mathrm{Zn}_{2} \mathrm{Ti}_{3} \mathrm{O}_{\dot{g}}$. As shown in Fig. 13, no noticeable change in the reduction rate

\begin{tabular}{|c|c|c|c|c|c|}
\hline \multirow[b]{2}{*}{ Sample } & \multirow[b]{2}{*}{ Reduction (\%) } & \multicolumn{4}{|c|}{ Crystalline phase (wt \%) } \\
\hline & & $\mathrm{Zn}_{2} \mathrm{TiO}_{4}$ & $\mathrm{Zn}_{2} \mathrm{Ti}_{3} \mathrm{O}_{8}$ & $\mathrm{ZnTiO}_{3}$ & $\mathrm{TiO}_{2}$ (rutile) \\
\hline $\begin{array}{l}\text { Z2T } \\
Z 2 T \\
Z 2 T \\
\text { Z3T } \\
\text { Z2T3-b }\end{array}$ & $\begin{array}{r}31 \\
74 \\
100 \\
53 \\
69\end{array}$ & $\begin{array}{r}76 \\
0 \\
0 \\
75 \\
0\end{array}$ & $\begin{array}{r}24 \\
85 \\
0 \\
25 \\
0\end{array}$ & $\begin{array}{r}0 \\
0 \\
0 \\
0 \\
33\end{array}$ & $\begin{array}{r}0 \\
15 \\
100 \\
0 \\
67\end{array}$ \\
\hline
\end{tabular}
was observed. For the solid Z2T3-b, consisting of $\mathrm{ZnTiO}_{3}$ and $\mathrm{TiO}_{2}$ (Table 1 ), $\mathrm{ZnTiO}_{3}$ reacted directly

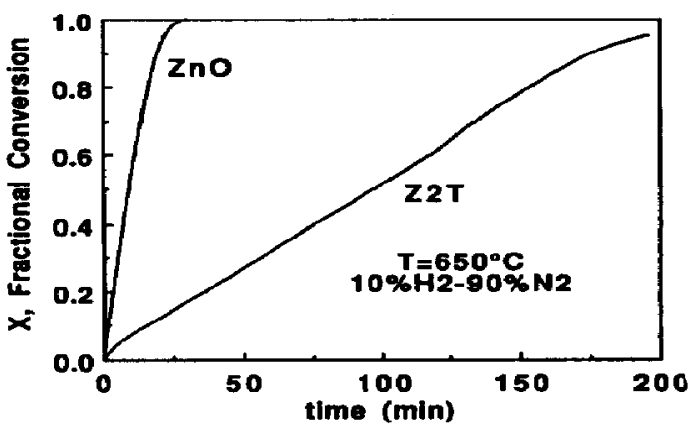

Fig. 13. Comparison of the experimental reduction profiles of $\mathrm{ZnO}$ and $\mathrm{ZZT}$ at $650^{\circ} \mathrm{C}$ in $10 \% \mathrm{H}_{2}-90 \% \mathrm{~N}_{2}$.

Table 3. XRD analyses of reduced $\mathrm{Zn}-\mathrm{Ti}-\mathrm{O}$ solids ${ }^{\dagger}$.

\footnotetext{
'Reduced in the TGA at $650^{\circ} \mathrm{C}$ in $10 \mathrm{~mol} \% \mathrm{H}_{2}-90 \mathrm{~mol} \% \mathrm{~N}_{2}$.
} 
with $\mathrm{H}_{2}$ to form $\mathrm{Zn}(\mathrm{g})$ and $\mathrm{TiO}_{2}$ (s). No intermediate chemical phases were detected. Although these XRD analyses revealed that the crystalline phase transformations of $\mathrm{Zn}_{2} \mathrm{TiO}_{4}$ and $\mathrm{ZnTiO}_{3}$ were different, these differences did not affect the initial reduction rate as discussed previously.

After partial reduction of $\mathrm{Zn}-\mathrm{Ti}-\mathrm{O}$ solids, changes in the color of the solids were observed. $\mathrm{ZnO}$ which was initially white, retained the same color after partial reduction. However, $\mathrm{Zn}-\mathrm{Ti}-\mathrm{O}$ solids, which were also initially white, took on a gray-blue color after partial reduction. Fully reduced $\mathrm{Zn}-\mathrm{Ti}-\mathrm{O}$ solids also had a gray color. This gray pigment was probably due to some surface reduction of $\mathrm{TiO}_{2}$. $\mathrm{Ti}_{3} \mathrm{O}_{5}$ has a blue-black color. No reduced $\mathrm{TiO}_{2}$ phase was detected by XRD analyses which indicated that no bulk reduction of $\mathrm{TiO}_{2}$ took place. In addition, the weight loss was not significantly different (within $5 \%$ ) from what would be expected from the loss of only $\mathrm{ZnO}$.

The solid structral changes in reduction were examined with a scanning electron microscope. Figure 14 shows the SEM micrographs of Z9T unreacted and
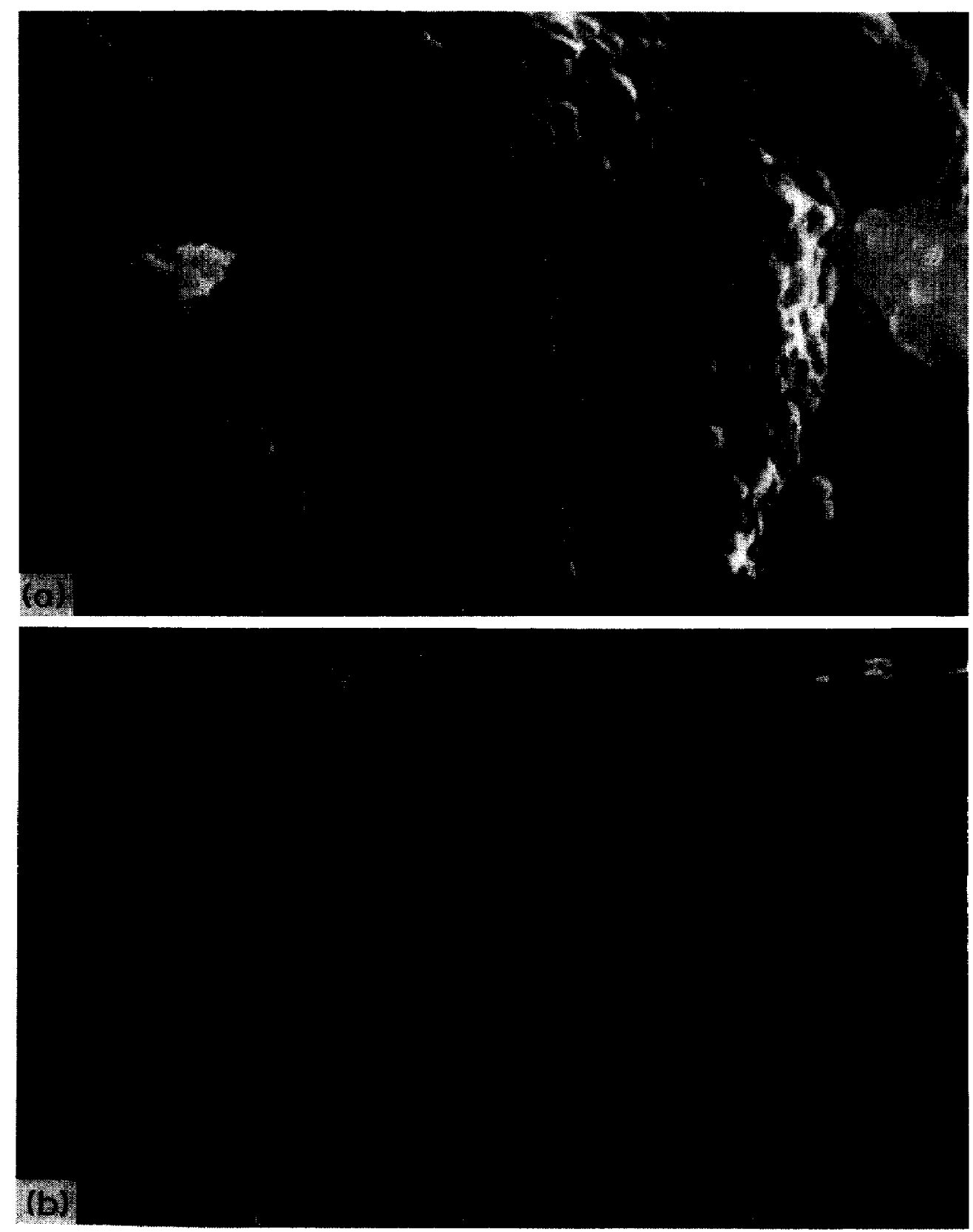

Fig. 14. SEM micrographs of Z9T calcined at $1000^{\circ} \mathrm{C}$ : (a) unreacted and (b) $45 \%$ reduced at $6500^{\circ} \mathrm{C}$ in $10 \%$ $\mathrm{H}_{2}-90 \% \mathrm{~N}_{2}$. 
partially reduced $(45 \%)$ at $650^{\circ} \mathrm{C}$ in $10 \mathrm{~mol} \% \mathrm{H}_{2}-$ $90 \mathrm{~mol} \% \mathrm{~N}_{2} . \mathrm{Z9T}$ is composed of a mixture of $\mathrm{ZnO}$ and $\mathrm{Zn}_{2} \mathrm{TiO}_{4}$. The unreacted solid [Fig. 14(a)] is composed of closely packed crystals (0.1-0.2 $\mu \mathrm{m}$ radius). After partial reduction [Fig. 14(b)], it is apparent that some crystals were more reactive than others. Holes which are approximately hexagonal in shape were left where these crystals had reacted with $\mathrm{H}_{2}$. It is surmised that these were $\mathrm{ZnO}$ crystals. $\mathrm{ZnO}$ crystallizes in the close-packed hexagonal system. Also, $\mathrm{ZnO}$ is more reactive in reduction than $\mathrm{Zn}_{2} \mathrm{TiO}_{4}$. As can be seen in Fig. 14(b), the sizes of the remaining crystals were relatively unchanged after $45 \%$ conversion.

\section{SUMMARY AND CONCLUSIONS}

A detailed study of hydrogen reduction of bulk $\mathrm{Zn}-\mathrm{Ti}-\mathrm{O}$ materials has been presented in this paper, aimed at determining whether $\mathrm{Zn}-\mathrm{Ti}-\mathrm{O}$ materials are intrinsically more resistive to reduction than $\mathrm{ZnO}$ and, if so, to identify the $\mathrm{Zn}-\mathrm{Ti}-\mathrm{O}$ composition(s) that suppress reduction rate the most.

In reaction with $\mathrm{H}_{2}-\mathrm{N}_{2}$ gas mixtures (zero \% $\mathrm{H}_{2} \mathrm{O}$ ), $\mathrm{Zn}-\mathrm{Ti}-\mathrm{O}$ solids had a lower reduction rate than $\mathrm{ZnO}$ at temperatures in the range of $550-1050^{\circ} \mathrm{C}$. With solids containing $(\mathrm{Zn} / \mathrm{Ti})$ atomic $\leqslant 3$, the initial reduction rate was ten times slower than that of $\mathrm{ZnO}$ at $700^{\circ} \mathrm{C}$. The activation energy of reduction was 37 and $24 \mathrm{kcal} \mathrm{mol}^{-1}$, respectively, for $\mathrm{Zn}-\mathrm{Ti}-\mathrm{O}$ and $\mathrm{ZnO}$.

All zinc titanate phases (i.e. $\mathrm{Zn}_{2} \mathrm{TiO}_{4}, \mathrm{Zn}_{2} \mathrm{Ti}_{3} \mathrm{O}_{8}$ and $\mathrm{ZnTiO}_{3}$ ) had the same initial rate of reduction. Increasing the amount of $\mathrm{TiO}_{2}$ beyond $25 \mathrm{~mol} \%$ ( $75 \mathrm{~mol} \% \mathrm{ZnO}$ ) did not correspondingly decrease the reduction rate in the absence of water vapor.

Water vapor inhibited the initial reduction rate of $\mathrm{ZnO}$ and $\mathrm{Zn}-\mathrm{Ti}-\mathrm{O}$ solids. However, increasing the water vapor content from 1 to $8 \mathrm{~mol} \%$ did not cause any further decrease in the reduction rate. Addition of water vapor was accompanied by changes in the activation energies to $44 \mathrm{kcal} \mathrm{mol}^{-1}$ for both $\mathrm{ZnO}$ and $\mathrm{Zn}-\mathrm{Ti}-\mathrm{O}$ solids. Increasing the relative amount of $\mathrm{TiO}_{2}$ from zero $\mathrm{mol} \%$ to $60 \mathrm{~mol} \%$ was accompanied by a corresponding decrease in the reduction rate.

From the reduction of partially sulfided $\mathrm{ZnO}$ and $\mathrm{Zn}-\mathrm{Ti}-\mathrm{O}$ solids, it appeared that $\mathrm{H}_{2} \mathrm{~S}$ inhibited the initial reduction rate similar to $\mathrm{H}_{2} \mathrm{O}$.

Two reduction sites are proposed for $\mathrm{ZnO}$ reduction. Type $A$ sites which are very reactive but can be poisoned by $\mathrm{H}_{2} \mathrm{O}$ and type $\mathrm{B}$ sites which are less reactive.

Titanium addition reduces the number of type $A$ sites. Approximately $25 \mathrm{~mol} \% \mathrm{TiO}_{2}$ (with $75 \mathrm{~mol} \%$ $\mathrm{ZnO}$ ) will completely eliminate type A sites. With $(\mathrm{Zn} / \mathrm{Ti})_{\text {atomic }} \leqslant 3$, another type of reaction sites, type $A^{\prime}$, less reactive than type $A$ sites, is involved in reduction. However, in the presence of $\mathrm{H}_{2} \mathrm{O}$ or $\mathrm{H}_{2} \mathrm{~S}$, these sites are eliminated and type $B$ sites dominate reduction. Type $B$ sites are less sensitive to titanium than type A sites, thus, requiring higher relative amounts of $\mathrm{TiO}_{2}$ to deactivate.

The geometric interaction of titanium with type $A$ and $B$ sites of zinc oxide is believed to cause elimination of these sites. Whether this property is unique to titanium is not clear at the present time. In the early work Hirschwald and Noack (1972) the reduction suppression imparted on $\mathrm{ZnO}$ by lithium, aluminum and gallium oxides was attributed to an electronic effect. On the other hand, as mentioned in the "Introduction", the addition of iron oxide in $\mathrm{ZnO}$ in the form of the compound zinc ferrite, $\mathrm{ZnFe}_{2} \mathrm{O}_{4}$, provides no stability to $\mathrm{ZnO}$ against reduction. This may be due to the fact that $\mathrm{ZnFe}_{2} \mathrm{O}_{4}$ breaks up into $\mathrm{ZnO}$ and $\mathrm{Fe}_{3} \mathrm{O}_{4}$ (or lower valence iron oxides) in a reducing gas atmosphere. In the present study, no free $\mathrm{ZnO}$ was found in the zinc titanate compounds reacted in hydrogen. Perhaps the ability of titanium to remain intimately associated with $\mathrm{ZnO}$ and, thus, possibly the reactive sites, in a reducing atmosphere can explain why $\mathrm{Zn}-\mathrm{Ti}-\mathrm{O}$ solids have lower reduction rates than $\mathrm{Zn}-\mathrm{Fe}-\mathrm{O}$ solids. Clearly, however, more information on the effect of various oxides on the reduction stability of $\mathrm{ZnO}$ is needed to elucidate the interaction mechanism. Work along these lines is presently in progress.

Acknowledgement - This research was supported by the U.S. Department of Energy/University Program under Contract No. DE-FG22-88PC88927.

\section{REFERENCES}

Boccuzzi, F., Borello, E., Zecchina, A., Bossi, A and Camia, M., 1978, Infrared study of $\mathrm{ZnO}$ surface properties $I$. Hydrogen and deuterium chemisorption at room temperature. $J$. Catal. 51, 150-159.

Bodenstein, M., 1927. The mechanism of the metallurgical production of zinc. Trans. Am. Electrochem. Soc. 51, $365-376$.

Bonasewicz, P., Littbarski, R. and Grunze, M., 1981, Adsorption phenomena, in Current Topics in Material Science (Edited by E. Kaldis), Vol. 7, pp. 371-409. North-Holland Publishing Company, New York.

Courty, P., Ajot, H., Marcilly, C. and Delmon, B., 1973, Oxydes mixtes ou en solution solide sous forme tres divisee obtenus per decomposition thermique de precurseurs amorphes. Powder Technol. 7, 21-38.

Dent, A. L. and Kokes, R. J., 1969, Hydrogenation of ethylene by zinc oxide. I. Role of slow hydrogen chemisorption. J. phys. Chem. 73, 3772-3780.

Eischens, R. P., Plisken, W. A. and Low, M. J. D., 1962, The infrared spectrum of hydrogen chemisorbed on zinc oxide. J. Catal. 1, 180-191.

Flytzani-Stephanopoulos, M., Gavalas, G. R., Jothimurugesan, K., Lew, S., Sharma, P. K., Bagajewicz, M. J. and Patrick, V., 1987, Detailed studies of novel regenerable sorbents for high-temperature coal-gas desulfurization. Final Report DOE/MC/22193-2582.

Flytzani-Stephanopoulos, M., Gavalas, G. R., Tamhankar, S. S. and Sharma, P. K., 1985, Novel sorbents for hightemperature regenerative $\mathrm{H}_{2} \mathrm{~S}$ removal. Final Report DOE/MC/20417-1898.

Gioia, F., Mura, G. and Viola, A., 1977, Experimental study of the direct reduction of sinterized zinc oxide by hydrogen. Chem. Eng. Sci. 32, 1401-1409.

Griffin, G. L. and Yates, J. T., Jr., 1982, Combined temper- 
ature-programmed desorption and infrared study of $\mathbf{H}_{2}$ chemisorption on ZnO. J. Catal. 73, 396-405.

Grindley, T. and Steinfeld, G., 1981, Development and testing of regenerable hot coal-gas desulfurization sorbents. Final Report DOE/MC/16545-1125.

Grindley, T. and Steinfeld, G., 1983, Zinc ferrite hydrogen sulfide absorbent. 3rd Annual Control Meeting on Contaminant Control in Hot Coal-derived Gas Streams. Report DOE/METC/84-6.

Grunze, M. and Hirschwald, W., 1974, Vacuum microbalance investigations on heterogeneous surface reaction mechanisms. J. Vac. Sci. Technol. 11, 424-428.

Grunze, M. and Hirschwald, W., 1975, Vacuum microbalance investigations on the pressure and temperature dependence of solid/gas reactions, in Progress in Vacuum Microbalance Techniques (Edited by $C$. Eyraud and $M$. Escoubes), Vol. 3, pp. 233-244. Eyden, New York.

Guger, C. E. and Manning. F. S., 1971, Kinetics of zinc oxide reduction with carbon monoxide. Met. Trans. 2, 3083-3090.

Hegedus, A. J. and Kiss, A. B., 1966, Thermogravimetrische Untersuchung der $\mathrm{ZnO}+\mathrm{H}_{2}$ - Reaktion in stromendem Wasserstoff. Mikrochim. Acta 4-5, 813-832.

Hirschwald, W. and Noack, D., 1972, Thermogravimetrische Untersuchung der Reduktionskinetik von Zinkoxid mit Wasserstoff. Zeit. Phys. Chemie Neue Folge 77, 1-20.
Jalan, V. and Wu, D., 1980, High temperature desulfurization of fuel gases for molten carbonate fuel cell power plants. Paper presented at the National Fuel Cell Seminar, San Diego, CA.

Kesavulu, V. and Taylor, H. S., 1960, Sites for hydrogen chemisorption on zinc oxide. J. phys. Chem. 64, 1124-1131.

Lew, S., 1990, High-temperature sulfidation and reduction of zinc titanate and zinc oxide sorbents. PhD dissertation, Massachusetts Institute of Technology, Cambridge, MA.

Lew, S., Jothimurugesan, $\mathbf{K}$. and Flytzani-Stephanopoulos, M., 1989, High-temperature $\mathrm{H}_{2} \mathrm{~S}$ removal from fuel gases by regenerable zinc oxide-titanium dioxide sorbents. Ind. Eng. Chem. Res. 28, 535-541.

Maier, C. G. and Ralston, O. C., 1928, The gaseous reduction of zinc. Trans. Am. Electrochem. Soc. 51, 339-363.

Marcilly, C., Courty, P. and Delmon, B., 1970, Preparation of highly dispersed mixed oxides and oxide solid solutions by pyrolysis and amorphous organic precursors. $\mathrm{J}$. Am. Ceram. Soc. 53, 56-57.

Matsuda, S. and Kato, A., 1983, Titanium oxide based catalysts - a review. Appl. Catal. 8, 149-165.

Truesdale, E. C. and Waring, R. K., 1944, Relative rates of reactions involved in reduction of zinc ores. $A I M E$ Trans. 159, 97-109. 